\title{
Facile and efficient recovery of mercury based on poly (amine-ester)-bearing metal-complexation and acidic aqueous solution-soluble groups
}

\author{
Daisuke Nagai $^{1}$, Akiko Nakazato ${ }^{1}$ and Hisatoyo Morinaga ${ }^{2}$ \\ Polymer Journal (2015) 47, 761-766; doi:10.1038/pj.2015.57; published online 2 September 2015
}

\section{INTRODUCTION}

Heavy metal pollution represents an important environmental problem due to the toxic effects of metals. The accumulation of heavy metals throughout the food chain leads to serious ecological and health problems. ${ }^{1}$ Mercury is universally recognized as one of the most toxic and dangerous non-biodegradable inorganic pollutants present in aquatic systems. ${ }^{2-8}$ Mercury is present in many products and processes in common use (for example, chloro-alkali production, pharmaceutical and cosmetic preparations, combustion of fossil fuels, electrical and electronics manufacturing plants, metal processing, metal plating, metal finishing, and pulp and paper industries), resulting in the contamination of aquatic systems. ${ }^{2-5,7,8}$

Conventional methods for the recovery of metals from water and wastewater include reduction, ${ }^{9,10}$ oxidation, ${ }^{11}$ solvent extraction, ${ }^{12,13}$ precipitation ${ }^{14,15}$ and adsorption. ${ }^{16-19}$ Of these, adsorption seems to be the most suitable method for recovery of metals due to its low cost, safety and high efficiency. ${ }^{20,21}$ Metal adsorption by polymers has been extensively studied; ${ }^{16-21}$ however, because nearly all polymers are insoluble in aqueous solutions of metal ions, adsorption must proceed heterogeneously, resulting in two important problems (low recovery and low adsorption rate), which represent a hurdle to practical use. Previously, we proposed an efficient recovery and facile process for metal recovery based on a water-soluble polyallylamine with side-chain thiourea groups for metal-complexation groups. ${ }^{22}$ Since the polymer is soluble in aqueous metal ion solutions, complexation proceeds homogeneously and efficiently. As complexation progresses, cross-linking takes place between the metal-complexation groups and the metal ions, precipitating the polymer complex, which can be easily separated by filtration.

For further development of a metal-recovery process utilizing a water-soluble polymer, we herein report a new facile and efficient recovery system based on a polymer-bearing metal-complexation and acidic aqueous solution-soluble groups. Figure 1 shows a schematic representation of our design: a polymer containing tertiary amine groups that are soluble in acidic aqueous solution on their protonation and that interact with metal ions. The polymer achieves homogeneous complexation with high-recovery efficiency and at a high rate. As complexation progresses, cross-linking takes place between the tertiary amine groups and the metal ions, precipitating the polymer complex, which can be easily separated by filtration. Because metal ion wastes are often produced under acidic conditions, effective recovery of metals in acidic aqueous solution is desirable. ${ }^{23}$ Because diamine and diacrylate are available abundantly, the selection of the poly (amine-ester) suitable to a target metal can result in the construction of a number of recovery systems.

\section{MATERIALS AND METHODS \\ Materials}

1,3-Di-4-piperidylpropane (Tokyo Kasei Kogyo, Tokyo, Japan, >97.0\%) was purified by recrystallization from hexane and dried under vacuum. 1,6hexanediol diacrylate (Alfa Aesar, Lamcashire, UK) was commercially available and used as received. Tetrahydrofuran (Wako Pure Chemical, Osaka, Japan, $>99.5 \%)$ was distilled and used. Mercury (II) chloride $\left(\mathrm{HgCl}_{2}\right.$, Wako Pure Chemical, >99.5\%), manganese (II) chloride tetrahydrate (Kanto Chemical, Tokyo, Japan, $>99.0 \%$ ), iron (III) chloride hexahydrate (Wako Pure Chemical, $>99.0 \%$ ), cobalt (II) chloride hexahydrate (Kanto Chemical, >99.0\%), nickel (II) chloride hexahydrate (Kanto Chemical, >98.0\%), copper (II) chloride (Wako Pure Chemical, $>95.0 \%$ ), ruthenium (III) chloride trihydrate (Kanto Chemical, $>98.0 \%$ ), rhodium (III) chloride hydrate (Aldrich, St Louis, MO, USA, $>99.9 \%)$, sodium tetrachloropalladate (II) $\left(\mathrm{Na}_{2} \mathrm{PdCl}_{4}\right.$, Tokyo Kasei Kogyo, >98.0\%), silver (I) nitrate (Kanto Chemical, >99.8\%), osmium (III) chloride hydrate (Alfa Aesar, 99.99\%), iridium (III) chloride trihydrate, (Aldrich, > 99.9\%), hydrogen hexachloroplatinate (IV) (Wako Pure Chemical, $>98.5 \%$ ) and sodium tetrachloroaurate (III) dihydrate (Wako Pure Chemical, $>95.0 \%$ ) were commercially available and used as received. Sodium chloride (Wako Pure Chemical, >99.5\%), sodium bromide (Wako Pure Chemical, 99.9\%), and sodium iodide (Wako Pure Chemical, >99.9\%) were used as received.

\section{Methods}

${ }^{1} \mathrm{H}$ nuclear magnetic resonance (NMR) spectra were recorded with JEOL JNM- $\lambda 500$ (Tokyo, Japan) using tetramethylsilane as an internal standard; the $\delta$

${ }^{1}$ Division of Molecular Science, Faculty of Science and Technology, Gunma University, Gunma, Japan and ${ }^{2}$ Faculty of Education and Human Sciences, Graduate Faculty of Interdisciplinary Research, University of Yamanashi, Yamanashi, Japan

Correspondence: Dr D Nagai, Division of Molecular Science, Faculty of Science and Technology, Gunma University, 1-5-1 Tenjin-cho, Kiryu, Gunma 376-8515, Japan.

E-mail: daisukenagai@gunma-u.ac.jp

Received 17 April 2015; revised 11 June 2015; accepted 24 June 2015; published online 2 September 2015 

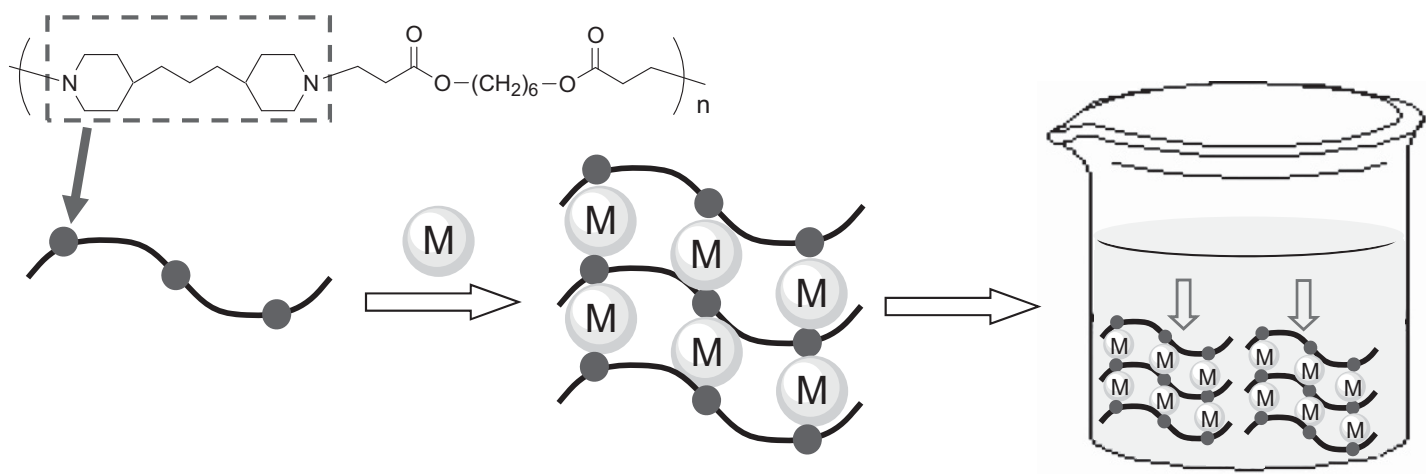

Homogeneous and efficient adsorption

Precipitation after adsorption

Easy isolation with filtration

Figure 1 Schematic representation of facile and high-recovery system of mercury by a polymer containing metal-complexation groups and soluble groups in acidic aqueous solution. A full color version of this figure is available at Polymer Journal online.

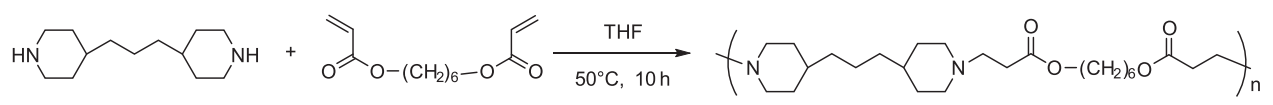

Scheme 1 Synthesis of poly(amine-ester) by polycondensation of 1,3-di-4-piperidylpropane and 1,6-hexanediol diacrylate.

values are given in p.p.m. Number-average $\left(M_{\mathrm{n}}\right)$ and weight-average $\left(M_{\mathrm{w}}\right)$ molecular weights were estimated by size-exclusion chromatography using a system consisting of a Hitachi L-7100 pump (Hitachi Ltd., Tokyo, Japan), Hitachi L-7490 refractive index detector (Hitachi Ltd) and polystyrene gel columns (Tosoh TSK gels $\alpha 2500$ and $\alpha 3000$ (TOSOH CORPORATION, Tokyo, Japan), whose limitations of size-exclusion are $1 \times 10^{4}$ and $1 \times 10^{5}$, respectively). Ultraviolet (UV)/visible (VIS) absorption spectra were recorded with a Hitachi U-3000 UV-Vis spectrometer (Hitachi Ltd).

\section{Synthesis of poly(amine-ester) - typical procedure}

Poly(amine-ester) was synthesized according to the reported procedure. ${ }^{24}$ To a solution of 1,3-di-4-piperidylpropane $(1.90 \mathrm{mmol}, 400 \mathrm{mg})$ in tetrahydrofuran $(5.00 \mathrm{ml}), 1,6$-hexanediol diacrylate $(1.90 \mathrm{mmol}, 430 \mathrm{mg})$ was added at $50^{\circ} \mathrm{C}$ and stirred at the same temperature for $48 \mathrm{~h}$ in air. The resulting mixture was poured into hexane $(200 \mathrm{ml})$. The resulting precipitate was collected by filtration with suction and dried in vacuo to obtain poly (amine-ester) (315 mg, 38\%).

$M_{\mathrm{n}}=8000, M_{\mathrm{w}} / M_{\mathrm{n}}=3.08 .{ }^{1} \mathrm{H} \mathrm{NMR}\left(500 \mathrm{MHz}, \mathrm{CDCl}_{3}, \delta\right.$, p.p.m., at rt): 1.13-1.77 $\left(2 \mathrm{H}+2 \mathrm{H}+2 \mathrm{H}+4 \mathrm{H}+2 \mathrm{H}+4 \mathrm{H}+4 \mathrm{H}, \quad\right.$ br, $\mathrm{m},-\mathrm{CH}\left(\mathrm{CH} H \mathrm{CH}_{2}\right)_{2} \mathrm{NCH}_{2}$ $\mathrm{CH}_{2}-,-\mathrm{CH}\left(\mathrm{CH}_{2} \mathrm{CH}_{2}\right)_{2} \mathrm{NCH}_{2} \mathrm{CH}_{2}-,-\mathrm{CH}\left(\mathrm{CHHCH}_{2}\right)_{2} \mathrm{NCH}_{2} \mathrm{CH}_{2}-,-\mathrm{CH}$ $\left(\mathrm{CH}_{2} \mathrm{CH}_{2}\right)_{2} \mathrm{NCH}_{2} \mathrm{CH}_{2}-, \quad-\mathrm{CH}\left(\mathrm{CH}_{2} \mathrm{CH}_{2}\right)_{2} \mathrm{NCH}_{2} \mathrm{CH}_{2}-, \quad-\mathrm{CH}\left(\mathrm{CH}_{2} \mathrm{CH}_{2}\right)$ ${ }_{2} \mathrm{NCH}_{2} \mathrm{CH}_{2} \mathrm{OCOCH}_{2} \mathrm{CH}_{2} \mathrm{CH}_{2}-, \quad-\mathrm{CH}\left(\mathrm{CH}_{2} \mathrm{CH}_{2}\right)_{2} \mathrm{NCH}_{2} \mathrm{CH}_{2} \mathrm{OCOCH}_{2} \mathrm{CH}_{2}$ $\left.\mathrm{CH}_{2}-\right), 1.93\left(2 \mathrm{H}\right.$, br, $\left.-\mathrm{CH}\left(\mathrm{CH}_{2} \mathrm{CHH}\right)_{2} \mathrm{NCH}_{2} \mathrm{CH}_{2}-\right), 2.51(4 \mathrm{H}$, br, $-\mathrm{CH}$ $\left.\left(\mathrm{CH}_{2} \mathrm{CH}_{2}\right)_{2} \mathrm{NCH}_{2} \mathrm{CH}_{2} \mathrm{OCOCH}_{2} \mathrm{CH}_{2}-\right), 2.64\left(4 \mathrm{H}, \mathrm{br},-\mathrm{CH}\left(\mathrm{CH}_{2} \mathrm{CH}_{2}\right)_{2} \mathrm{NCH}_{2}\right.$ $\left.\mathrm{CH}_{2} \mathrm{OCOCH}_{2} \mathrm{CH}_{2}-\right), 2.87\left(2 \mathrm{H}\right.$, br, $\left.-\mathrm{CH}\left(\mathrm{CH}_{2} \mathrm{CHH}\right)_{2} \mathrm{NCH}_{2} \mathrm{CH}_{2}-\right), 4.06$ $\left(4 \mathrm{H}, \mathrm{t}, J=7.00,-\mathrm{CH}\left(\mathrm{CH}_{2} \mathrm{CH}_{2}\right)_{2} \mathrm{NCH}_{2} \mathrm{CH}_{2} \mathrm{OCOCH}_{2} \mathrm{CH}_{2}-\right.$ ).

\section{Metal recovery-typical procedure}

An aqueous solution of poly(amine-ester) $(\mathrm{pH} \mathrm{1,5.00} \mathrm{ml,} 0.3 \mathrm{wt} \%)$ was added into an aqueous solution of $\mathrm{HgCl}_{2}(\mathrm{pH} 1,5.00 \mathrm{ml}, 4 \mathrm{~mm})$, and the mixture was stirred at ambient temperature for $2 \mathrm{~h}$. The resulting precipitate was separated by filtration (pore size of filter; $0.45 \mu \mathrm{m})$, and aliquot $(0.250 \mathrm{ml})$ of the filtrate was removed for sampling. After appropriate dilution, the metal concentration in the solution was determined by UV/VIS spectrometer. The recovery amount was calculated based on the following equation. $\mathrm{pH}$ was adjusted by $\mathrm{HCl}$ aq.

Recovery amount $\left(\mathrm{g}_{\text {metal }} / \mathrm{g}_{\text {poly. }}\right)=\mathrm{M}$ of metal $\times$ recovery amount $(\mathrm{mmol}) /$ weight of polymer used $(\mathrm{g})$.

\section{RESULTS AND DISCUSSION}

Poly(amine-ester)s were synthesized by polyaddition of 1,3-di4-piperidylpropane with 1,6-hexanediol diacrylate in tetrahydrofuran at $50{ }^{\circ} \mathrm{C}$ (Scheme 1). The polymer was soluble in water at $\mathrm{pH}<2$ but insoluble at $\mathrm{pH}>3$, because protonation of the nitrogen atoms led to hydrophilicity.

We investigated the recovery of $\mathrm{Hg}^{\mathrm{II}}$ using poly(amine-ester). An aqueous solution of poly(amine-ester) ( $\mathrm{pH} \mathrm{1,5.00} \mathrm{ml,} 0.3 \mathrm{wt} \%$ ) was added to a $1.0 \mathrm{M}$ aqueous solution of $\mathrm{HgCl}_{2}\left(\mathrm{pH} 1,5.00 \mathrm{ml}, \mathrm{Hg}^{\mathrm{II}}\right.$ concentration: $4.00 \mathrm{~mm}$ ), resulting in instant precipitation (Figure 2) (dissolution of poly(amine-ester) to an aqueous solution ( $\mathrm{pH} 1,0.3 \mathrm{wt}$ \%) decreased to $\mathrm{pH}$ 3. Addition of $\mathrm{HgCl}_{2}$ to an aqueous solution of $\mathrm{pH} 3$ (4 mM) resulted in the dissolution of $\mathrm{HgCl}_{2}$. Therefore, $\mathrm{HgCl}_{2}$ is not spontaneously precipitated by $\mathrm{pH}$ change due to polymer addition). The precipitate was separated by filtration, and the concentration of $\mathrm{Hg}^{\mathrm{II}}$ in the filtrate was measured by UV/vis spectroscopy, yielding a recovery efficiency of $96 \%$. Thus, poly (amine-ester) was effective for $\mathrm{Hg}^{\mathrm{II}}$ recovery, and the polymer complex could easily be separated by filtration.

The effect of $\mathrm{pH}$ on the recovery of $\mathrm{Hg}^{\mathrm{II}}$ by poly(amine-ester) was examined (Figure 3). Interestingly, the recovery behavior was quite consistent with the solubility of the polymers in $\mathrm{Hg}^{\mathrm{II}}$ aqueous solution, i.e., the recovery efficiency increased significantly at $\mathrm{pH} 2$. No $\mathrm{Hg}^{\mathrm{II}}$ ions were precipitated at any $\mathrm{pH}$. This demonstrated that homogeneous complexation significantly enhanced recovery.

Figure 4 shows ${ }^{1} \mathrm{H}$ NMR spectra of the polymers with different recovery amounts. As the recovery amount increased, the proton signals adjacent to the nitrogen atom ( $\mathrm{a}, \mathrm{b}$ and $\mathrm{h}$ ) shifted to lower field, indicating that the nitrogen atoms contributed to the 
complexation. In $0.1 \mathrm{M} \mathrm{Cl}^{-}$aqueous solution $(=\mathrm{pH} 1)$, the species present are $\mathrm{HgCl}_{2}, \mathrm{HgCl}^{3-}$ and $\mathrm{HgCl}_{4}{ }^{25}$ Three probable interactions were considered (Scheme 2): (a) cross-linking by coordination of the free nitrogen atom to $\mathrm{HgCl}_{2}$; (b) ion exchange between $\mathrm{Cl}^{-}$and $\mathrm{HgCl}^{3-}$; and (c) cross-linking by ion exchange between $\mathrm{Cl}^{-}$and $\mathrm{HgCl}_{4}^{2-}$.

Because the homogeneous recovery process using poly(amine-ester) is expected to result in a fast recovery rate, the kinetics was studied. The recovery of $\mathrm{Hg}^{\mathrm{II}}$ by poly(amine-ester) was very fast, finishing within $10 \mathrm{~min}$, because the homogeneous adsorption took place (Figure 5). The experimental kinetic data were fitted with a pseudo-

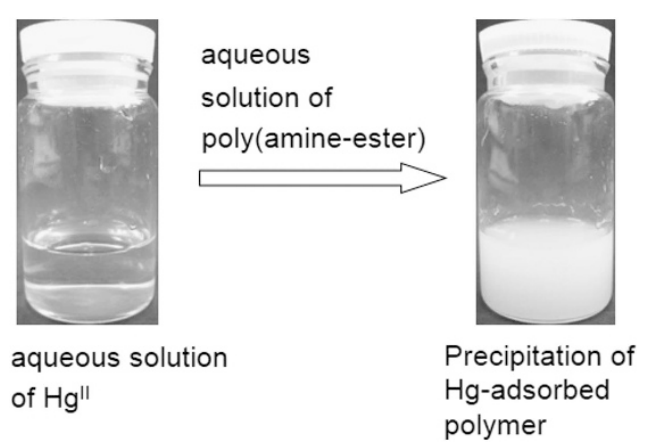

Figure 2 Photographs of poly(amine-ester) before and after $\mathrm{Hg}^{\prime l}$ recovery. Conditions: aqueous solution of $\mathrm{Hg}^{\mathrm{Il}}: 5 \mathrm{ml}\left(\mathrm{pH} 1 ; \mathrm{Hg}^{\prime l}\right.$ concentration: $4.0 \mathrm{~mm}$ ); that of poly(amine-ester): $5 \mathrm{ml} \mathrm{(pH} \mathrm{1;0.3} \mathrm{wt \% );} \mathrm{ambient}$ temperature. first-order kinetic equation:

$$
\log \left(Q_{\mathrm{e}}-Q_{\mathrm{t}}\right)=\log Q_{\mathrm{e}}-k t / 2.303
$$

where $Q_{\mathrm{e}}$ is the equilibrium recovery amount of $\mathrm{Hg}^{\mathrm{II}}\left(\mathrm{g}_{\mathrm{Hg}} / \mathrm{g}_{\text {poly. }}\right), Q_{\mathrm{t}}$ is the recovery amount $\left(\mathrm{g}_{\mathrm{Hg}} / \mathrm{g}_{\text {poly. }}\right)$ at time $t$, and $k$ is the rate constant $\left(\min ^{-1}\right)$. For the recovery of $\mathrm{Hg}^{\mathrm{II}}$ by poly(amine-ester), $k$ was estimated to be $0.338 \mathrm{~min}^{-1}$ (correlation coefficient, $R^{2}=0.9657$ ). These results demonstrated that improved polymer solubility accelerates the recovery of $\mathrm{Hg}^{\mathrm{II}}$.

The effect of the initial concentration of $\mathrm{Hg}^{\mathrm{II}}$ on the amount of mercury recovered by the poly(amine-ester) was examined (Figure 6).

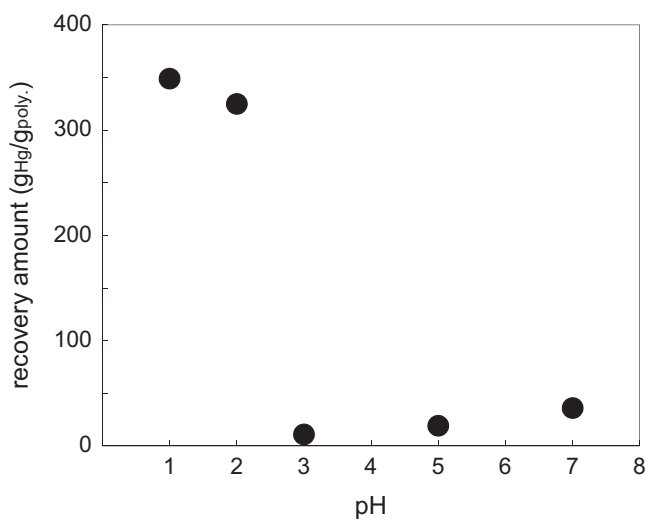

Figure 3 Effects of $\mathrm{pH}$ on the $\mathrm{Hg}$ "l recovery by poly(amine-ester). Conditions: aqueous solution of $\mathrm{Hg}^{\prime \prime}: 5 \mathrm{ml}(4.0 \mathrm{~mm})$; that of poly(amine-ester): $5 \mathrm{ml}(0.3$ wt\%); ambient temperature for $1 \mathrm{~h}$.

a recovery amount: $126 \mathrm{mgHg} / \mathrm{gpoly}$.)

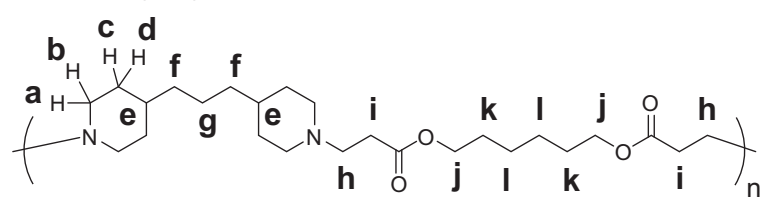

b recovery amount: $380 \mathrm{mgHg} / \mathrm{gpoly}$.)

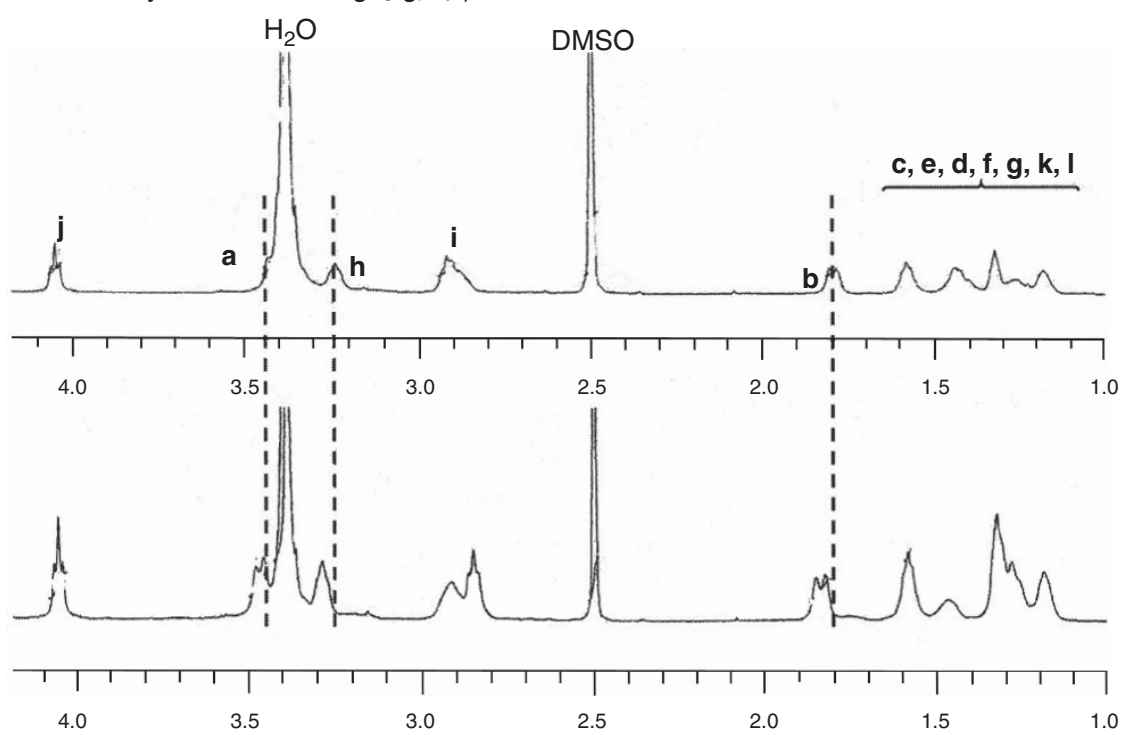

Figure $4 \mathrm{lH}$ NMR spectra (DMSO, rt) of poly(amine-ester)s with different recovery amounts (upper: $126 \mathrm{mg} \mathrm{Hg}_{\mathrm{g}} / \mathrm{g}_{\text {poly.; }}$ lower: $487 \mathrm{mg} \mathrm{Hg} / \mathrm{g}_{\text {poly. }}$ ). NMR, nuclear magnetic resonance. 
<smiles>[Z]C(C)CCCC1CCN(C([CH])C)CC1</smiles><smiles>CCCCCC1CCN(C(C)C)CC1</smiles>

b<smiles>[CH][N+]1([CH])CCC(CCCCC)CC1</smiles><smiles>CCCCC1CC[N+]([O-])(CC)CC1</smiles>

C

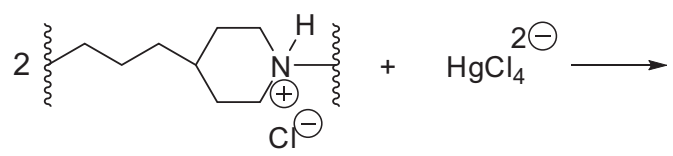

Scheme 2 Probable interaction between tertiary amine groups and $\mathrm{Hg}$ species.

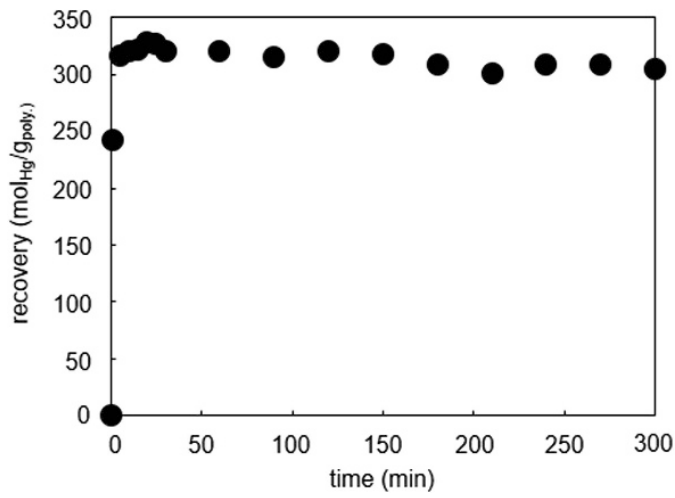

Figure 5 Changes of recovery of $\mathrm{Hg}^{\prime \prime}$ by poly(amine-ester). Conditions: aqueous solution of $\mathrm{Hg}^{\prime \prime}: 5 \mathrm{ml}\left(\mathrm{pH} 1\right.$; $\mathrm{Hg}^{\prime \prime}$ concentration: $\left.4.0 \mathrm{~mm}\right)$; that of poly(amine-ester): $5 \mathrm{ml}$ (pH 1; $0.3 \mathrm{wt} \%$ ); ambient temperature.

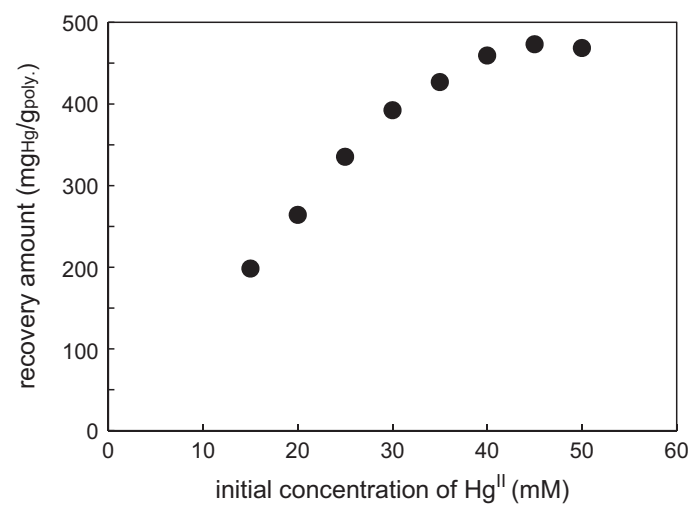

Figure 6 Recovery amounts of poly(amine-ester) as function of initial concentration of $\mathrm{Hg}^{\prime \prime}$. Conditions: aqueous solution of $\mathrm{Hg}^{\prime \prime}: 5 \mathrm{ml}(\mathrm{pH} 1)$; that of poly(amine-ester): $5 \mathrm{ml}(\mathrm{pH} \mathrm{1;} 0.3 \mathrm{wt} \%$ ); ambient temperature for $1 \mathrm{~h}$.
The recovery amount increased with increasing $\mathrm{Hg}^{\mathrm{II}}$ concentration and tended to approach the plateau region $\sim 45 \mathrm{~mm}$. Based on the plateau region, the maximum recovery by the poly(amine-ester) was evaluated as $487 \mathrm{mg}_{\mathrm{Hg}} /$ poly. Table 1 compares the maximum recovery amounts of different types of adsorbent. Our polymer had a satisfactory recovery ability, and because a wide variety of diamine and diacrylate are available the proportion of adsorption sites in polymer structure can increase, resulting in a larger recovery amount.

The recovery of various metals by poly(amine-ester) was examined using a metal ion concentration of $45 \mathrm{~mm}$, which was the optimum concentration for $\mathrm{Hg}^{\mathrm{II}}$ recovery. As summarized in Table 2, metals with large atomic radii tended to instantly give rise to cross-linking precipitates. This selectivity is ascribed to the high affinity of the tertiary amine groups for soft metal ions. It is noteworthy that the recovery amounts for all of the metals were very high (123-520 $\mathrm{mg}_{\text {metal }} / \mathrm{g}_{\text {poly. }}$ ).

Some industrial wastewaters contain, in addition to toxic heavy metal ions, large quantities of other salts such as sodium chloride. Generally, the sole effect of this presence is a high ionic strength that slightly modifies the values of the equilibrium constants, without introducing new reactions in the system. This is not the case for solutions containing $\mathrm{Hg}^{\mathrm{II}}$ ions, which are known to form very stable complexes with halide ions. ${ }^{26}$ The formation of such strong complexes can result in a masking effect that significantly affects the performance of an adsorbent. In this study, sodium halides $(\mathrm{NaCl}, \mathrm{NaBr}$ and $\mathrm{NaI})$ were chosen as model salts to investigate the effect of halide ions on the recovery of $\mathrm{Hg}^{\mathrm{II}}$ ions by the poly(amine-ester). The effect was studied by carrying out a series of recovery experiments in solutions of $\mathrm{Hg}^{\mathrm{II}}$ containing various $\mathrm{NaX}$ concentrations. Table 3 shows effect of $\mathrm{NaX}$ concentrations on the recovery of $\mathrm{Hg}^{\mathrm{II}}$ by the poly(amine-ester). It is noteworthy that the recovery efficiency of $\mathrm{Hg}^{\mathrm{II}}$ did not decrease in every case, indicating that $\mathrm{Hg}^{\mathrm{II}}$ recovery by the poly(amine-ester) was not affected by the presence of halide ions because of its high-recovery ability.

In summary, we have successfully developed a facile and efficient recovery process for metals based on a poly(amine-ester) consisting 
Table 1 Comparison of the maximum recovery amounts of mercury ions on different adsorbents

\begin{tabular}{|c|c|c|c|}
\hline Entry & Adsorbent & $\begin{array}{l}Q_{m} \\
\left(m g_{H g} / g_{p o l y .}\right)\end{array}$ & Ref. \\
\hline 1 & Styrene-divinylbenzene & 20 & Lezzi et al. ${ }^{27}$ \\
\hline 2 & Ethylenediamine-modified PMMA & 30 & Denizli et al. ${ }^{28}$ \\
\hline 3 & Dithiocabamate-modified PSt & 32 & Denizli et al. ${ }^{29}$ \\
\hline 4 & $\begin{array}{l}\text { Poly(glycidyl methacrylate- } \\
\text { divinylbenzene) }\end{array}$ & 40 & Jyo et al. ${ }^{30}$ \\
\hline 5 & Dihizone-modified PHEMA & 42 & Salih et al. ${ }^{31}$ \\
\hline 6 & Sulfur chlorinated wax modified PSt & 50 & Binman et al. ${ }^{32}$ \\
\hline 7 & Acrylamide modified PEGDMA & 54 & Kesenci et al. ${ }^{33}$ \\
\hline 8 & Soy protein hydrogel & 60 & Hwang et al. ${ }^{34}$ \\
\hline 9 & Procion Blue MX-3G-modified PVA & 69 & Liu et al. ${ }^{35}$ \\
\hline 10 & $N$-hydroxymethyl thioamide & 72 & Shah et al. ${ }^{36}$ \\
\hline 11 & Dithizone-modified poly(vinyl pyridine) & 144 & Cestari et al. ${ }^{37}$ \\
\hline 12 & $\begin{array}{l}\text { 3-trimethoxysilyl-1-propanethiol-modi- } \\
\text { fied silica }\end{array}$ & 184 & Delacour et al. ${ }^{38}$ \\
\hline 13 & Polyethyleneimine-modified silica gel & 200 & Rivas et al. ${ }^{39}$ \\
\hline 14 & Poly( $N$-vinylimidazole) & 200 & Arpa et al. ${ }^{40}$ \\
\hline 15 & Thiazolidine-modified PHEMA & 222 & Navarro et al. ${ }^{41}$ \\
\hline 16 & Polyethyleneimine-modified cellulose & 288 & Denizli et al. ${ }^{42}$ \\
\hline 17 & Polyethyleneimine-modified PHEMA & 334 & Becker et al. ${ }^{43}$ \\
\hline 18 & Amberlite IRC 718 & 360 & Atia et al. ${ }^{44}$ \\
\hline 19 & Thiol-modified poly(GMA-DVB) & 400 & Denizli et al. ${ }^{45}$ \\
\hline 20 & $\begin{array}{l}N \text {-methacryloyl-(L)-cysteine modified } \\
\text { PHEMA }\end{array}$ & 1018 & Denizli et al. ${ }^{26}$ \\
\hline 21 & $\begin{array}{l}N \text {-methacryloyl-(L)-histidine modified } \\
\text { PHEMA }\end{array}$ & 1234 & Denizli et al. ${ }^{46}$ \\
\hline 22 & Poly(amine-ester) & 487 & This work \\
\hline
\end{tabular}

Table 2 Recovery (gmetal/gpoly.) of various metal ions by poly(amineester) $^{\mathrm{a}}$

\begin{tabular}{ccccc}
\hline $\mathrm{Mn}^{\prime \prime}$ & $\mathrm{Fe}^{\prime \prime \prime}$ & $\mathrm{Co}$ & $\mathrm{Ni}$ & $\mathrm{Cu}^{\prime \prime \prime}$ \\
$\times$ & $\times$ & $\times$ & $\times$ & $\times$ \\
\hline & $\mathrm{Ru}^{\prime \prime \prime}$ & $\mathrm{Rh}^{\prime \prime \prime}$ & $\mathrm{Pd}^{\prime \prime}$ & $\mathrm{Ag}^{\prime \prime}$ \\
$\times$ & 123 & 265 & $\times$ \\
& $\mathrm{Os}^{\prime \prime \prime}$ & $\mathrm{Ir}^{\prime \prime \prime}$ & $\mathrm{Pt}^{\mathrm{IV}}$ & $\mathrm{Au}^{\prime \prime \prime}$ \\
& 112 & 404 & 469 & 520 \\
\hline
\end{tabular}

aConditions: Aqueous solution of metal ion: $5 \mathrm{ml}$ ( $\mathrm{pH} \mathrm{1;}$; metal concentration: $45 \mathrm{~mm}$ ); aqueous solution of polymer: $5 \mathrm{ml}(\mathrm{pH} \mathrm{1;} 0.3 \mathrm{wt} \%)$; ambient temperature; reaction time: $1 \mathrm{~h}$.

of metal-complexation and acidic aqueous solution-soluble groups. Since the polymer is soluble in acidic aqueous solutions, the metal-complexation proceeds homogeneously and efficiently. As metal-complexation progresses, cross-linking takes place between the metal-complexation groups and the metal ions, precipitating the polymer complex, which can be easily separated by filtration. $\mathrm{Hg}^{\mathrm{II}}$ recovery was completed within $10 \mathrm{~min}$, and the maximum amount of mercury recovered by the poly(amine-ester) $\left(487 \mathrm{mg}_{\mathrm{Hg}} / \mathrm{g}_{\text {poly. }}\right)$ was satisfactory. The polymer was also capable of recovering other metals such as $\mathrm{Rh}^{\mathrm{III}}, \mathrm{Pd}^{\mathrm{II}}$, $\mathrm{Os}^{\mathrm{III}}, \mathrm{Ir}^{\mathrm{III}}, \mathrm{Pt}^{\mathrm{IV}}$ and $\mathrm{Au}^{\mathrm{III}}$ in large amounts. This polymer, bearing metal-complexation and acidic aqueous solution-soluble groups, is expected to be applicable as an efficient
Table 3 The effect of other salts $(\mathrm{NaX})$ on the adsorption of $\mathrm{Hg}^{\mathrm{Il}}$ by $\mathrm{P} 1^{\mathrm{a}}$

\begin{tabular}{|c|c|c|c|c|c|}
\hline Entry & Salt & $\begin{array}{c}\text { Concentration } \\
\text { (mм) }\end{array}$ & $\begin{array}{c}\text { Recovery } \\
\text { amount }\left(g_{H g} \text { ) }\right. \\
g_{\text {poly. }} \text { ) }\end{array}$ & $\begin{array}{c}\text { Recovery } \\
\text { amount }\left(\mathrm{mol}_{\mathrm{Hg}}{ }^{\prime}\right. \\
\left.\text { mol }_{\text {poly. }}\right)\end{array}$ & Recovery (\%) \\
\hline 1 & - & 0 & 0.745 & 0.344 & 96 \\
\hline 2 & $\mathrm{NaCl}$ & 1.25 & 0.742 & 0.341 & 96 \\
\hline 3 & $\mathrm{NaCl}$ & 2.5 & 0.708 & 0.325 & 91 \\
\hline 4 & $\mathrm{NaBr}$ & 1.25 & 0.758 & 0.349 & 98 \\
\hline 5 & $\mathrm{NaBr}$ & 2.5 & 0.767 & 0.354 & 99 \\
\hline 6 & $\mathrm{Nal}$ & 1.25 & 0.745 & 0.342 & 96 \\
\hline 7 & $\mathrm{Nal}$ & 2.5 & 0.745 & 0.342 & 96 \\
\hline
\end{tabular}

aConditions: Aqueous solution of metal ion: $5 \mathrm{ml}$ ( $\mathrm{pH} \mathrm{1;} \mathrm{metal} \mathrm{concentration:} 45 \mathrm{~mm}$ ); aqueous solution of polymer: $5 \mathrm{ml}(\mathrm{pH} \mathrm{1;} 0.3 \mathrm{wt} \%)$; ambient temperature for $2 \mathrm{~h}$.

recovery material for metals. We are now currently examining the selectivity of $\mathrm{Hg}^{\mathrm{II}}$ ion from a mixture of other metal ions.

\section{CONFLICT OF INTEREST}

The authors declare no conflict of interest.

1 Forestner, U. \& Wittman, A. Metal Pollution in the Aquatic Environment (SpringerVerlag, New York, NY, USA, 1979).

2 Vieira, R. S. \& Beppu, M. M. Dynamic and static adsorption and desorption of $\mathrm{Hg}(\mathrm{II})$ ions on chitosan membranes and spheres. Water Res. 40, 1726-1734 (2006).

3 Denizli, A. \& Senel, S. Mercury removal from synthetic solutions using poly (2-hydroxyethylmethacrylate) gel beads modified with poly(ethyleneimine). React. Funct. Polym. 55, 121-130 (2003).

4 Boening, D. W. Ecological effects, transport, and fate of mercury: a general review. Chemosphere 40, 1335-1351 (2000).

5 Uludag, Y., Ozbelge, H. O. \& Yilmaz, L. Removal of mercury from aqueous solutions via polymer-enhanced ultrafiltration. J. Membr. Sci. 129, 93-99 (1997).

6 Ravichandran, M. Interactions between mercury and dissolved organic matter-a review. Chemosphere 55, 319-331 (2004).

7 Pacyna, J. M. \& Munch, J. Anthropogenic mercury emission in Europe. Water Air Soil Pollut. 56, 51-61 (1991)

8 Di Natale, F, Lancia, A, Molino, A, Di Natale, M, Karatza, D \& Musmarra, D Capture of mercury ions by natural and industrial materials. J. Hazard. Mater. 132, 220-225 (2006).

9 Parajuli, D., Adhikari, C. R., Kawakita, H., Yamada, S., Ohno, K. \& Inoue, K. Chestnut pallicie for the recovery of gold. Bioresour. Technol. 100, 1000-1002 (2009).

10 Macaskie, L. E., Creamer, N. J., Essa, A. M. M. \& Brown, N. L. A new approach for the recovery of precious metals from electronic scrap. Biotechnol. Bioeng. 96, 631-639 (2007)

11 Zhao, X., Guo, L. B., Zhang, B. F., Liu, H. J. \& Qu, J. H. Envrion. Sci. Technol. 9 , 1384-1392 (1996).

12 Nguyen, H. T., Masayuki, W. \& Takaumi, K. Solvent extraction of palladium(II) with various ketones from nitric acid medium. Solvent Extr. Ion Exc. 25, 407-416 (2007).

13 Wang, J. S. \& Wai, C. M. Dissolution of precious metals in supercritical carbon dioxide. Ind. Eng. Chem. Res. 44, 922-926 (2005).

14 Koseoglu, H. \& Kitis, M. The recovery of silver from mining wastewaters using hybrid cyanidation and high-pressure membrane process. Miner. Eng. 22, 440-444 (2009).

15 Sadyrbaeva, T. Z. Separation of copper(II) from palladium(II) and platinum(IV) by di(2-ethylhexyl)phosphoric acid-base liquid membranes during electrodialysis. J. Membr. Sci. 275, 195-201 (2006).

16 Li, F., Bao, C., Zhang, J., Sun, Q., Kong, W., Han, X. \& Wang, Y. Synthesis of chemically modified chitosan with 2,5-dimercapto-1,3,4-thiodiazole and its adsorption abilities for Au(III), Pd(II), and Pt(IV). J. Appl. Polym. Sci. 113, 1604-1610 (2009).

17 Adhikari, C. R., Parajuli, D., Kawakita, H., Inoue, K., Ohno, K. \& Harada, H. Dimethylamine-modified waste paper for the recovery of precious metals. Environ. Sci. Technol. 42, 5486-5491 (2008).

18 Ngah, W. S. W., Teong, L. C. \& Hanafiah, M. A. K. M. Adsorption of dyes and heavy metal ions by chitosan composites: a review. Carbohydrate Polym. 83, 1446-1456 (2011).

19 Eang, R., Liao, X. \& Shi, B. Adsorption behaviors of Pt(II) and Pd(II) on collagen fiber immobilized bayberry tannin. Ind. Eng. Chem. Res. 44, 4221-4226 (2005).

20 Zhou, L., Liu, J. \& Liu, Z. Adsorption of platinum(IV) and palladium(II) from aqueous solution by thiourea-modified chitosan microsphere. J. Hazard. Mater. 172. 439-446 (2009) 
21 Fujiwara, K., Ramesh, A., Maki, T., Hasegawa, H. \& Ueda, K. Adsorption of platinum (IV), palladium(II) and gold(III) from aqueous solutions onto L-lysine modified crosslinked chitosan. J. Hazard. Mater. 146, 39-50 (2007).

22 Nagai, D., Yoshida, M., Kishi, T., Morinaga, H., Hara, Y., Kawakami, S. \& Inoue, K. A facile and high-recovery material for rare-metals based on water-soluble polyallylamine with side-chain thiourea groups. Chem. Commun. 49, 6852-6854 (2013)

23 Maruyama, T., Matsushita, H., Shimada, Y., Kamata, I., Hanaki, M., Sonokawa, S., Kamiya, N. \& Goto, M. Proteins and protein-rich biomass as environmental-friendly adsorbents selective for precious metal ions. Environ. Sci. Technol. 41, 1359-1364 (2007)

24 Gao, C., Tang, W. \& Yan, D. Synthesis and characterization of water-soluble hyperbranched poly(ester-amine)s from diacrylates and diamine. J. Polym. Sci. A: Polym. Chem. 40, 2340-2349 (2002).

25 Puanngam, M. \& Unob, F. Preparation and use of chemically modified MCM-41 and silica gel as selective adsorbents for $\mathrm{Hg}(\mathrm{II})$ ions. J. Hazard. Mater. 154, 578-587 (2008).

26 Denizli, A., Sanli, N., Garlpcan, B., Patir, S. \& Alsamcak, G. Methacryloylamidoglutamic acid incorporated porous poly(methyl methacrylate) beads for heavy-metal removal. Ind. Eng. Chem. Res. 43, 6095-6101 (2004).

27 Lezzi, A., Cobianco, S. \& Roggrero, A. Synthesis of thiol chelating resins and their adsorption properties toward heavy metal ions. J. Polym. Sci. A: Polym. Chem. 32, 1877-1883 (1994).

28 Denizli, A., Ozkan, G. \& Arica, Y. Preparation and characterization of magnetic polymethylmethacrylate microbeads carrying ethylene diamine for removal of $\mathrm{Cu}(\mathrm{II})$, $\mathrm{Cd}(\mathrm{II}), \mathrm{Pb}(\mathrm{II})$, and $\mathrm{Hg}(\mathrm{II})$ from aqueous solutions. J. Appl. Polym. Sci. 78 81-89 (2000).

29 Denizli, A., Kesenci, K., Arica, Y. \& Piskin, E. Dithiocarbamate-incorporated monosize polystyrene microspheres for selective removal of mercury ions. React. Funct. Polym. 44, 235-243 (2000).

30 Jyo, A., Matsufune, S., Ono, H. \& Egawa, H. Preparation of phosphoric acid resins with large cation exchange capacities from macroreticular poly(glycidyl methacrylate-codivinylbenzene) beads and their behavior in uptake of metal ions. J. Appl. Polym. Sci. 63, 1327-1334 (1997).

31 Salih, B., Say, R., Denizli, A., Genc, O. \& Piskin, E. Determination of inorganic and organic mercury compoundsby capillary gas chromatography coupled with atomic absorption spectrometry after preconcentration on dithizone-anchored polu(ethylene glycol dimethacrylate-hydroxyethylmethacrylate) microbeads. Anal. Chim. Acta 371, 177-185 (1998)

32 Binman, S., Belfer, S. \& Shani, A. Metal sorption properties of sulfur-chlorinated jojoba bound to polystyrene beads. J. Appl. Polym. Sci. 63, 625-633 (1997).
33 Kesenci, K., Say, R. \& Denizli, A. Removak of heavy metal ions from water by using poly(ethyleneglycoldimethacrylate-co-acrylamide). Eur. Polym. J. 38, 1443-1448 (2002).

34 Hwang, D. C. \& Damondaran, S. Metal-chelating properties and biodegradability of an ethylenediaminetetraacetic acid dianhydride modified soy protein hydrogel. J. Appl. Polym. Sci. 64, 891-901 (1997).

35 Liu, C. Y., Chang, H. T. \& Hu, C. C. Thermal behavior and crystal structure of dichloro [6-amino-1,3-dimethyl-5-(2-chlorophenylazo)uracilato] gold(III). Inorg. Chim. Acta 172, 151-156 (1990).

36 Shah, S. \& Devi, S. Preconcentration of mercury(II) on dithizone anchored poly (vinylpyridine) support. React. Funct. Polym. 31, 1-9 (1996).

37 Cestari, A. R. \& Airoldi, C. Chemisorption on thiol-silicas: divalent cations as a function of $\mathrm{pH}$ and primary amines on thiol-mercury adsorbed. J. Colloid Interface Sci. 195 338-342 (1997).

38 Delacour, M. L., Gailliez, E., Bacquet, M. \& Morcellet, M. Poly(ethyleneimine) coated onto silica gels: adsorption capacity toward lead and mercury. J. Appl. Polym. Sci. 73, 899-906 (1999).

39 Rivas, B. R., Maturana, H. A., Molina, M., Gomez-Anton, M. R. \& Pierola, I. F. Metal ion binding properties of poly(N-vinylimidazole) hydrogels. J. Appl. Polym. Sci. 67, 1109-1118 (1998).

40 Arpa, C., Saglam, A., Bektas, S., Patir, S., Genc, O. \& Denizli, A. Adsorption of mercury (II) ions by poly(hidroxyethylmethacrylate) adsorbents with thiazolidine groups. Adsorp. Sci. Technol. 20, 203-213 (2002).

41 Navarro, R. R., Sumi, K., Fujii, N. \& Matsumara, M. Mercury removal from wastewater using porous cellulose carrier modified with polyethyleneimine. Water Res. 30 2488-2494 (1996)

42 Denizli, A., Senel, S., Alsancal, G., Tuzmen, N. \& Say, R. Merury removal from synthetic solutions using poly(2-hydroxyethylmethacrylat) gel beads modified with poly(ethyleneimine). React. Funct. Polym. 55, 121-130 (2003).

43 Becker, N. S. C. \& Eldridge, R. J. Selective recovery of mercury(II) from industrial wastewaters I. Use of a chelating ion exchanger regenerated with brine. React. Funct. Polym. 21, 5-14 (1993).

44 Atia, A., Donia, A. M. \& Yousif, A. M. Synthesis of amine and thio chelating resins and study of their interaction with zinc(II), cadmiunm(II) and mercury(II) ions in their aqueous solutions. React. Funct. Polym. 56, 75-82 (2003).

45 Denizli, A., Garipcan, B., Emir, S., Patir, S. \& Say, R. Heavy metal ion adsorption properties of methacrylamidocysteine containing porous poly(hydroxylethyl methacrylate) chelating beads. Adsorp. Sci. Technol. 20, 607-617 (2002).

46 Ringbom, A. in Cours de Chimie Analytique (Dunod, Paris, France, 1967). 